\title{
The Effect of Steroids and Ammonium Chloride Acidosis on Phosphoenolpyruvate Carboxykinase in Rat Kidney Cortex
}

\author{
II. THE KINETICS OF ENZYME INDUCTION
}

\author{
I. D. Longshaw, G. A. O. Alleyne, and C. I. Pogson \\ From the Department of Biochemistry, University of Bristol, The Medical \\ School, Bristol, United Kingdom
}

A в S T R A C T The kinetics of the induction of rat kidney phosphoenolpyruvate carboxykinase activity after triamcinolone and ammonium chloride administration have been investigated with a view to the further differentiation of the two processes.

The half-life of kidney phosphoenolpyruvate carboxykinase activity, as measured from the decay curve after a single doses of triamcinolone, is approximately $1.4 \mathrm{hr}$. This compares with a half-life for the enzyme from acidotic kidney of approximately $3.4 \mathrm{hr}$.

Analysis of the data indicates that the induction of phosphoenolpyruvate carboxykinase activity by triamcinolone may be attributed to an increase in de novo protein synthesis. Induction by acidosis is qualitatively distinct and is partly attributed to a reduction in the rate of decay of phosphoenolpyruvate carboxykinase activity.

The activities of the gluconeogenic enzymes glucose-6phosphatase, fructose-1,6-diphosphatase, and phosphoenolpyruvate carboxykinase in both liver and kidney have been measured in animals separately treated with triamcinolone and ammonium chloride. Triamcinolone significantly increases the activities of liver phosphoenolpyruvate carboxykinase, kidney glucose-6-phosphatase, and kidney phosphoenolpyruvate carboxykinase only; ammonium chloride stimulates a $200 \%$ increase in kidney phosphoenolpyruvate carboxykinase, but has no effect on the other enzymes.

The induction processes whereby triamcinolone in-

Dr. Longshaw's present address is Imperial Chemicals Industries Ltd., Pharmaceuticals Division, Mereside, Alderley Park, Macclesfield, Cheshire, U. K. Dr. Alleyne's present address is M.R.C. Tropical Metabolism Research Unit, University of the West Indies, Mona, Kingston 7, Jamaica.

Received for publication 15 February 1972. creases phosphoenolpyruvate carboxykinase activities in liver and kidney differ quantitatively.

\section{INTRODUCTION}

Phosphoenolpyruvate carboxykinase (PEPCK) ${ }^{1}$ activity in rat kidney is increased during ammonium chloride acidosis and after administration of the synthetic glucocorticoid, triamcinolone ( $9 \alpha$-fluoro-16 $\alpha, 17 \alpha$-isopropylidenedioxy-1-dehydrocorticosterone) $(1,2)$. Although the increased PEPCK activities are reflected in increased antibody titers, the two processes of induction may be differentiated through their response to actinomycin D (1). Previous studies of PEPCK induction in kidney have involved measurement of enzyme activities at single time-points after treatment with inducer (1-3). It is of interest, therefore, to compare the time-courses of enzyme induction by ammonium chloride and triamcinolone with a view to their further differentiation and the eventual elucidation of the mechanisms involved. In this paper we present the results of a study of the kinetics of PEPCK induction and turnover in rat kidney under these two conditions and discuss the metabolic basis for these findings.

\section{METHODS}

Animals. Male Wistar rats $(120-200 \mathrm{~g})$ were used throughout. Rats were fed diet $41 \mathrm{~B}$ (4), and were allowed water or $0.18 \% \mathrm{NaCl}$ ad lib. $0.18 \% \mathrm{NaCl}$ replaced water in experiments involving $\mathrm{NH}_{4} \mathrm{Cl}$-induced acidosis; in these experiments, $\mathrm{NaCl}$ was given to both controls and experimental animals.

Adrenal glands were removed by means of a midline dorsal incision under ether anaesthesia. Adrenalectomized

\footnotetext{
${ }^{1}$ Abbreviation used in this paper: PEPCK, phosphoenolpyruvate carboxykinase.
} 
animals were given $1 \% \mathrm{NaCl}$ in place of water and were left for 5 days before further use.

Triamcinolone acetonide was administered by intramuscular or intraperitoneal injection of the suspension appropriately diluted in $0.9 \% \mathrm{NaCl}$. Acidosis was induced by the administration of $0.4 \mathrm{M} \mathrm{NH}_{4} \mathrm{Cl}$ in water by stomach tube. Controls received either injections of $0.9 \% \mathrm{NaCl}$ or $0.4 \mathrm{M}$ $\mathrm{NaCl}$ by stomach tube as appropriate.

Tissue extractions. Animals were killed between 0700 and $0900 \mathrm{hr}$ by decapitation. The kidneys, and where appropriate, the livers were rapidly removed, rinsed in icecold $0.9 \% \mathrm{NaCl}$, freed of capsules and connective tissue, blotted, and weighed. One kidney, or approximately $1 \mathrm{~g}$ liver, was then homogenised in 9 vol of $0.154 \mathrm{M} \mathrm{KCl}, 5 \mathrm{~mm}$ 2-mercaptoethanol at $0^{\circ} \mathrm{C}$ in a motor-driven all-glass tissue grinder (Kontes Glass Co., Vineland, N. J.). Portions of these homogenates were stored for assay of total protein. The remainder was centrifuged at approximately $1000 \mathrm{~g}$ for $2 \mathrm{~min}$ (MSE Minor, VWR United Corp., Crawley, U. K.) to remove large particles of cell debris. Samples of this first supernate were stored at $0^{\circ} \mathrm{C}$ for the subsequent assay of glucose-6-phosphatase. Approximately 1.5 $\mathrm{ml}$ of each supernate was further centrifuged at $12,000 \mathrm{~g}$ for $8 \mathrm{~min}$ at $4^{\circ} \mathrm{C}$ (Eppendorf Zentrifuge 3200, V. A. Howe Ltd., London). The resuiting clear supernates were stored at $0^{\circ} \mathrm{C}$ and used for subsequent assay of fructose-1,6-diphosphatase, PEPCK, and soluble protein.

Assay procedures. Glucose-6-phosphatase activity was measured in a stopped-assay procedure as described by Nordlie and Arion (5). Glucose formation was measured with glucose oxidase (6).

Fructose-1,6-diphosphatase was assayed substantially as described by Underwood and Newsholme (7). The medium consisted of $50 \mathrm{~mm}$ Tris $\mathrm{Cl}, 5 \mathrm{~mm} \mathrm{MgSO}, 20 \mathrm{~mm} 2-\mathrm{mer}$ captoethanol, $50 \mu \mathrm{M}$ fructose-1,6-diphosphate, $0.2 \mathrm{~mm}$ NA$\mathrm{DP}^{+}$, and $30 \mu \mathrm{g}$ each of phosphoglucose isomerase, glucose6-phosphate dehydrogenase, and 6-phosphogluconate dehydrogenase in a final volume of $3.0 \mathrm{ml}, \mathrm{pH}$ 7.5. Reactions were initiated by addition of fructose-1,6-diphosphate.

PEPCK was assayed as described previously (1). Protein concentrations (in $2 \mathrm{~N} \mathrm{NaOH}$ ) were measured by the biuret method (8). Blood $\mathrm{pH}$ determinations were made on a Radiometer Astrup $\mathrm{pH}$ meter (V. A. Howe Ltd., London). A unit of enzyme activity is defined as that amount which catalyzes the formation of $1 \mu$ mole of product per $\min$ at $30^{\circ} \mathrm{C}$ (glucose-6-phosphatase and fructose-1,6-diphosphatase) or $37^{\circ} \mathrm{C}$ (PEPCK).

Calculation of kinetic data. Decay curves were fitted to equation 1, where $E_{t}=$ PEPCK at time "t,"

$$
\mathrm{E}_{\mathrm{t}}-E_{0}=\left(\mathrm{E}^{\prime}-\mathrm{E}_{0}\right) \mathrm{e}^{-\mathrm{k}^{\prime} \mathrm{t}}
$$

$E_{o}=[P E P C K]$ final value, $E^{\prime}=[P E P C K]$ at $t=0$, i.e., the initial (highest) value, and $\mathrm{k}^{\prime}=$ the first order rate constant for the decay of enzyme activity (9). This procedure was carried out with the aid of an ICL475 computer (International Computers Ltd., Reading, U. K.).

Subsequent calculations were made using a HewlettPackard 9100B bench top calculator (Hewlett-Packard Co., Palo Alto, Calif.).

Materials. Biochemicals and enzymes were from the Boehringer Corp. (London) Ltd. Tris, as Trizma base, and 2-mercaptoethanol were from Sigma Chemical Co., St. Louis, Mo. Triamcinolone acetonide (Adcortyl) was a kind gift from E. R. Squibb \& Sons Ltd., Speke, Liverpool, U. K.

\section{RESULTS}

Expression of results. In most experiments, results were expressed in four different ways, viz., $(a)$ enzymic activity per gram wet tissue, $(b)$ activity per milligram total protein, $(c)$ activity per milligram soluble protein, and $(d)$ activity per $100 \mathrm{~g}$ rat body weight. The arguments supporting such an approach have been fully discussed by Freedland and Harper (10). Since there were no significant changes in tissue mass or protein content during the time-courses of our experiments, variations in enzyme activities, if any, were reflected similarly in all four modes of expression, irrespective of the parameter used.

The masses of rat liver and kidneys, expressed as percentages of the total animal body weight, were 5.3 $\pm 0.1 \%$ and $0.82 \pm 0.01 \%$, respectively (mean \pm SEM, $\mathrm{n}$ $=51$ in both cases).

Effects of triamcinolone and $\mathrm{NH}_{4} \mathrm{Cl}$ on glucose-6phosphatase, fructose 1,6-diphosphatase, and PEPCK in rat liver and kidney. Of the gluconeogenic enzymes assayed in liver extracts, only PEPCK showed significantly increased activity (approximately 100\%) after $48 \mathrm{hr}$ of triamcinolone administration to normal fed 150-g rats (Table I). This observation is in agreement with previous reports (11-13). Glucose-6-phosphatase and fructose-1,6-diphosphatase activities were similar to those in control animals. Measurements at 72 and $96 \mathrm{hr}$ confirmed this insensitivity to induction by triamcinolone. This lack of responsiveness of glucose-6-phosphatase contrasts with an earlier report of the efficacy of hydrocortisone as an inducer of this enzyme (14); this discrepancy may be attributable to dietary differences between the two experiments.

In kidney, in contrast, glucose-6-phosphatase concentrations were more than doubled by triamcinolone. At the same time, PEPCK activity was increased by more than $300 \%$, while fructose-1,6-diphosphatase alone was unresponsive (Table I). These results are in accord with those reported earlier (3).

Table II shows the results of a similar experiment in which $\mathrm{NH}_{4} \mathrm{Cl}$ administration by stomach tube replaced triamcinolone injection. The dosage employed was sufficient to elicit maximal responses. The liver gluconeogenic enzymes were unresponsive to acidosis over the $48 \mathrm{hr}$ period. In kidney, PEPCK activities were increased more than $200 \%$, while those of glucose-6phosphatase and fructose-1,6-diphosphatase were similar to control values.

The differences between the control values for kidney PEPCK activities in Tables I and II is attributed to variation between batches of animals, rather than to the administration of $0.4 \mathrm{M} \mathrm{NaCl}$ to the acidotic-control group; this treatment has been shown in other experiments to be without effect on PEPCK activity. 
TABLE I

Effect of Triamcinolone Administration on Gluconeogenic Enzyme Activities of Rat Liver and Kidney

\begin{tabular}{|c|c|c|c|c|c|c|c|}
\hline & & & $\begin{array}{c}\mathrm{U} / \mathrm{g} \\
\text { wet weight }\end{array}$ & $\begin{array}{c}\mathrm{mU} / \mathrm{mg} \\
\text { total protein }\end{array}$ & $\begin{array}{c}\mathrm{mU} / \mathrm{mg} \\
\text { soluble protein }\end{array}$ & $\begin{array}{c}\mathrm{U} / 100 \mathrm{~g} \\
\text { body weight }\end{array}$ & Significance \\
\hline \multirow[t]{6}{*}{ Liver } & \multirow[t]{2}{*}{ G6Pase } & Control & $7.5 \pm 0.3$ & $68 \pm 5$ & $95 \pm 5$ & $40 \pm 2$ & \multirow{2}{*}{ NS } \\
\hline & & Steroid & $8.1 \pm 0.4$ & $72 \pm 5$ & $109 \pm 7$ & $56 \pm 3$ & \\
\hline & \multirow[t]{2}{*}{ FDPase } & Control & $9.9 \pm 0.9$ & $90 \pm 11$ & $125 \pm 11$ & $53 \pm 5$ & \multirow{2}{*}{ NS } \\
\hline & & Steroid & $10.4 \pm 0.3$ & $93 \pm 3$ & $140 \pm 1$ & $72 \pm 2$ & \\
\hline & \multirow[t]{2}{*}{ PEPCK } & Control & $2.1 \pm 0.2$ & $19 \pm 1$ & $26 \pm 3$ & $11 \pm 1$ & \multirow{2}{*}{$P<0.01$} \\
\hline & & Steroid & $4.4 \pm 0.5$ & $39 \pm 3$ & $59 \pm 5$ & $30 \pm 3$ & \\
\hline \multirow[t]{6}{*}{ Kidney } & \multirow[t]{2}{*}{ G6Pase } & Control & $3.6 \pm 0.4$ & $32 \pm 4$ & $52 \pm 8$ & $3.0 \pm 0.4$ & \multirow{2}{*}{$P<0.005$} \\
\hline & & Steroid & $8.2 \pm 0.3$ & $69 \pm 3$ & $120 \pm 8$ & $7.8 \pm 0.3$ & \\
\hline & \multirow[t]{2}{*}{ FDPase } & Control & $11.3 \pm 0.1$ & $100 \pm 4$ & $161 \pm 7$ & $9.5 \pm 0.2$ & \multirow{2}{*}{ NS } \\
\hline & & Steroid & $12.4 \pm 0.8$ & $104 \pm 4$ & $181 \pm 7$ & $11.9 \pm 0.7$ & \\
\hline & \multirow{2}{*}{ PEPCK } & Control & $2.6 \pm 0.2$ & $23 \pm 2$ & $38 \pm 4$ & $2.2 \pm 0.2$ & \multirow{2}{*}{$P<0.001$} \\
\hline & & Steroid & $11.3 \pm 0.4$ & $95 \pm 1$ & $165 \pm 7$ & $10.9 \pm 0.3$ & \\
\hline
\end{tabular}

150- to $200-\mathrm{g}$ rats were injected intraperitoneally with $2.5 \mathrm{mg} / 100 \mathrm{~g}$ body weight of triamcinolone acetonide ("steroid") or a similar volume of $0.9 \% \mathrm{NaCl}$ ("control"). Four injections were given at 12-hr intervals; animals were killed at $48 \mathrm{hr}$, and the enzymes were subsequently assayed as described in the Methods section. Results are expressed as means \pm SEM of three observations in all cases.

FDPase, fructose-1,6-diphosphatase; G6Pase, glucose-6-phosphatase.

Time-course of PEPCK induction by triamcinolone. Fig. 1 shows the increase in kidney PEPCK activity after intramuscular injection of triamcinolone. Similar results were obtained in an experiment in which the steroid was administered by intraperitoneal injection. The increase in PEPCK activity was in all cases preceded by a lag period of approximately $2 \mathrm{hr}$.

Time-course of the decay of PEPCK activity after triamcinolone. Normal fed rats given a single injection of triamcinolone $(2.5 \mathrm{mg} / 130 \mathrm{~g}$ rat $)$ still showed high values for kidney PEPCK activities at 5 days after treatment. Most of the rats so treated died at 6 days. Postmortem inspection revealed that fat reserves were severely depleted. To avoid any problems of "adrenal rebound," animals were subsequently totally adrenalectomized 5 days before administration of steroid. The time-course of PEPCK induction in adrenalectomized animals was checked and was found to be similar to that observed in normal rats. Fig. 2 shows the decay in kidney PEPCK activity after injection of a

TABLE II

Effects of $\mathrm{NH}_{4} \mathrm{Cl}$ Administration on Gluconeogenic Enzyme Activities of Rat Liver and Kidney

\begin{tabular}{|c|c|c|c|c|c|c|c|}
\hline & & & $\begin{array}{c}\mathrm{U} / \mathrm{g} \\
\text { wet weight }\end{array}$ & $\begin{array}{c}\mathrm{mU} / \mathrm{mg} \\
\text { total protein }\end{array}$ & $\begin{array}{c}\mathrm{mU} / \mathrm{mg} \\
\text { soluble protein }\end{array}$ & $\begin{array}{c}\mathrm{U} / 100 \mathrm{~g} \\
\text { body weight }\end{array}$ & Significance \\
\hline \multirow[t]{3}{*}{ Liver } & G6Pase & $\begin{array}{l}\text { Control } \\
\text { Acidotic }\end{array}$ & $\begin{array}{r}10.5 \pm 0.8 \\
9.0 \pm 0.4\end{array}$ & $\begin{array}{l}75 \pm 7 \\
60 \pm 3\end{array}$ & $\begin{array}{c}121 \pm 12 \\
99 \pm 1\end{array}$ & $\begin{array}{l}34 \pm 2 \\
29 \pm 1\end{array}$ & NS \\
\hline & FDPase & $\begin{array}{l}\text { Control } \\
\text { Acidotic }\end{array}$ & $\begin{array}{l}12.7 \pm 0.3 \\
12.2 \pm 0.3\end{array}$ & $\begin{array}{l}91 \pm 2 \\
81 \pm 3\end{array}$ & $\begin{array}{l}146 \pm 3 \\
134 \pm 3\end{array}$ & $\begin{array}{l}42 \pm 2 \\
39 \pm 1\end{array}$ & NS \\
\hline & PEPCK & $\begin{array}{l}\text { Control } \\
\text { Acidotic }\end{array}$ & $\begin{array}{l}6.1 \pm 0.3 \\
7.4 \pm 0.7\end{array}$ & $\begin{array}{l}46 \pm 4 \\
49 \pm 3\end{array}$ & $\begin{array}{l}73 \pm 6 \\
82 \pm 7\end{array}$ & $\begin{array}{l}20 \pm 0.3 \\
24 \pm 3\end{array}$ & NS \\
\hline \multirow[t]{3}{*}{ Kidney } & G6Pase & $\begin{array}{l}\text { Control } \\
\text { Acidotic }\end{array}$ & $\begin{array}{l}4.2 \pm 0.1 \\
4.3 \pm 0.2\end{array}$ & $\begin{array}{l}39 \pm 5 \\
46 \pm 4\end{array}$ & $\begin{array}{l}64 \pm 6 \\
63 \pm 3\end{array}$ & $\begin{array}{l}3.2 \pm 0.1 \\
3.5 \pm 0.3\end{array}$ & NS \\
\hline & FDPase & $\begin{array}{l}\text { Control } \\
\text { Acidotic }\end{array}$ & $\begin{array}{l}11.9 \pm 0.3 \\
10.2 \pm 0.7\end{array}$ & $\begin{array}{l}106 \pm 11 \\
110 \pm 9\end{array}$ & $\begin{array}{l}179 \pm 10 \\
151 \pm 8\end{array}$ & $\begin{array}{l}9.0 \pm 0.4 \\
8.2 \pm 0.4\end{array}$ & NS \\
\hline & PEPCK & $\begin{array}{l}\text { Control } \\
\text { Acidotic }\end{array}$ & $\begin{array}{r}7.4 \pm 0.5 \\
24.9 \pm 1.0\end{array}$ & $\begin{array}{r}66 \pm 6 \\
269 \pm 6\end{array}$ & $\begin{array}{l}112 \pm 8 \\
373 \pm 18\end{array}$ & $\begin{array}{r}5.6 \pm 0.3 \\
20.4 \pm 0.8\end{array}$ & $P<0.001$ \\
\hline
\end{tabular}

150- to 200-g rats were given four doses of $5 \mathrm{ml} 0.4 \mathrm{M} \mathrm{NH} \mathrm{Nl}_{4}$ ("acidotic") or $5 \mathrm{ml} 0.4 \mathrm{M} \mathrm{NaCl}$ ("control") per $200 \mathrm{~g}$ body weight at 12-hr intervals. Animals were killed at $48 \mathrm{hr}$, and the enzymes were subsequently assayed as described in the Methods section. Results are expressed as means ISEM of four observations in all cases.

FDPase, fructose-1,6-diphosphatase; G6Pase, glucose-6-phosphatase. 


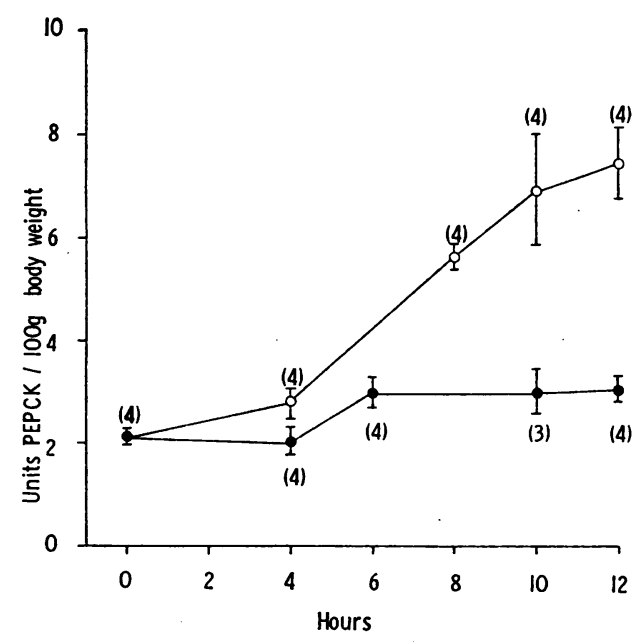

FIGURE 1 Time-course of the induction of kidney PEPCK by triamcinolone. Rats (approximately $200 \mathrm{~g}$ ) were injected intramuscularly with $2.5 \mathrm{mg} / 100 \mathrm{~g}$ body weight of triamcinolone acetonide $(O)$ or a similar volume of $0.9 \% \mathrm{NaCl}$ (controls, - ) at zero time $(0700 \mathrm{hr})$. Tissue extractions and assays were performed as described in the Methods section. Results are expressed as means ISEM; the number of observations is given in parentheses.

low dose of triamcinolone $(0.1 \mathrm{mg} / 130 \mathrm{~g}$ rat $)$. In all experiments, it was observed that final values were significantly above those of the controls. The reason for this is unknown, but it may be related to retention of a very small proportion of triamcinolone in the kidney even after several half-lives (15).

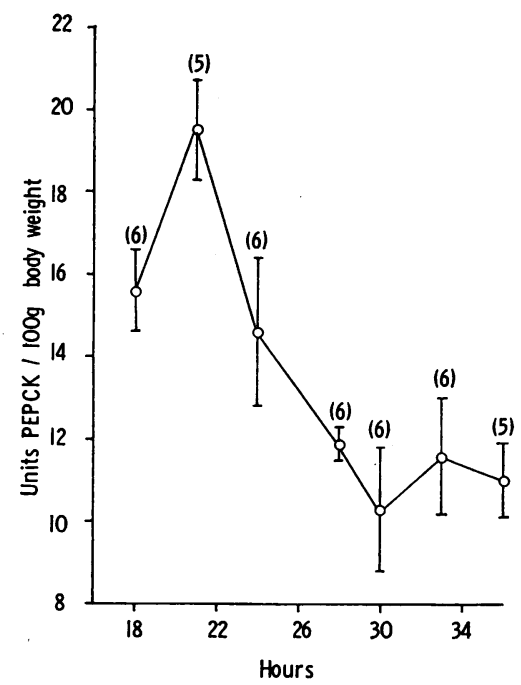

FIGURE 2 Time-course of the decay of kidney PEPCK activity after triamcinolone. Adrenalectomized rats (120 $150 \mathrm{~g}$ ) were given a single intraperitoneal injection of triamcinolone acetonide at zero time ( 5 days postoperative). Tissue extractions and assays were performed as described in the Methods section. Results are expressed as means ISEM; the number of observations is given in parentheses.

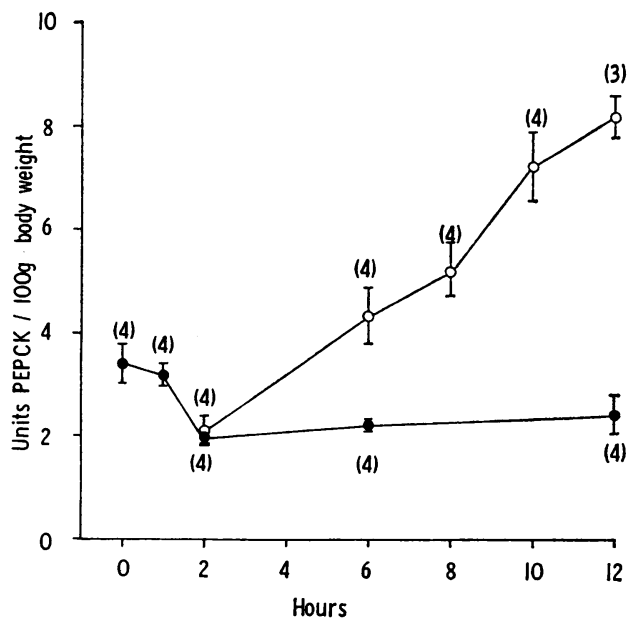

Figure 3 Time-course of the increase in kidney PEPCK activity after $\mathrm{NH}_{4} \mathrm{Cl}$ feeding. Rats (approximately $200 \mathrm{~g}$ ) were given either $5 \mathrm{ml} 0.4 \mathrm{M} \mathrm{NH}{ }_{4} \mathrm{Cl}$ experimental (O), or $5 \mathrm{ml} 0.4 \mathrm{M} \mathrm{NaCl}$ (controls, - ) per $100 \mathrm{~g}$ body weight by stomach tube. Tissue extractions and assays were performed as described in the Methods section. Results are expressed as means ISEM; the number of observations is given in parentheses.

Time-course of PEPCK induction by $\mathrm{NH}_{4} \mathrm{Cl}$. Oral admission of $\mathrm{NH}_{4} \mathrm{Cl}$ leads to a significant degree of acidosis after $2 \mathrm{hr}$ (16). PEPCK activity is only slightly increased over control values at $4 \mathrm{hr}$. The lag period of approximately $2 \mathrm{hr}$ is similar to that seen with induction by steroids. After $4 \mathrm{hr}$ activity increases rapidly (Fig. 3). Control values remain unchanged.

Time-course of the decay of PEPCK activity after $\mathrm{NH}_{4} \mathrm{Cl}$. The reduction in kidney PEPCK activity was followed in animals rendered alkalotic at zero time (Fig. 4). In a similar experiment, not shown, blood $\mathrm{pH}$ values measured $3 \mathrm{hr}$ after $\mathrm{NaHCO}_{s}$ administration were $7.54 \pm 0.07$ and $7.62 \pm 0.02$ for the "acidotic" and control groups, respectively ( $n=4$ in both cases). PEPCK activity in "acidotic" kidneys fell rapidly and was only slightly greater than control values at $12 \mathrm{hr}$. Extracts of kidneys from control animals treated with $\mathrm{NaHCO}_{3}$ initially exhibited a reduction of PEPCK activity, presumably due to the onset of alkalosis (16) ; values later increased, and by $25 \mathrm{hr}$ were the same as those in kidneys from experimental animals and those observed in "normal" control kidneys.

Time-course of liver PEPCK induction by triamcinolone. The activity of liver PEPCK after intramuscular injection of triamcinolone was monitored over a $12 \mathrm{hr}$ period to determine whether PEPCK induction exhibited similar kinetics in both liver and kidney.

As distinct from that in kidney, the situation in the liver is complicated by the diurnal rhythmicity of 


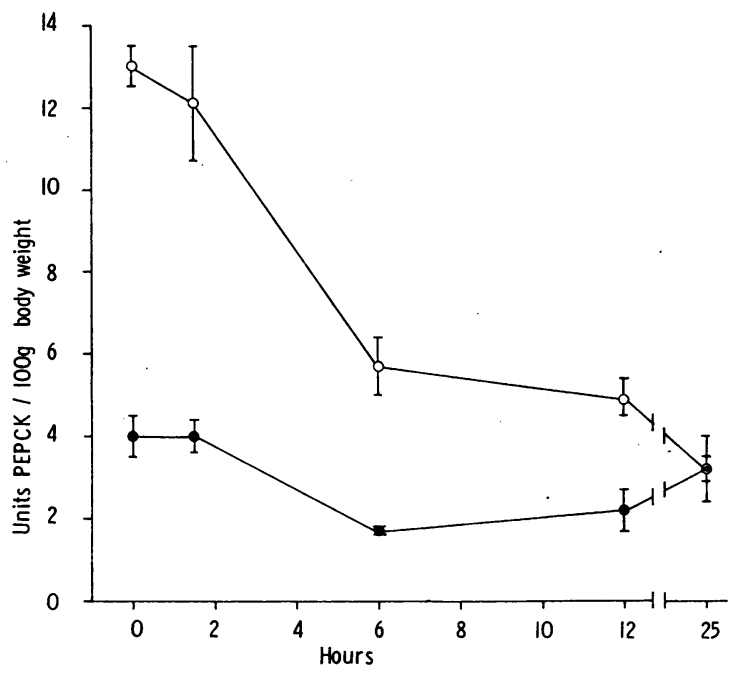

FIgure 4 Time-course of the decay of kidney PEPCK activity after administration of $\mathrm{NaHCO}_{3}$ to acidotic rats. Rats (approximately $200 \mathrm{~g}$ ) were rendered acidotic (O) by four administrations of $5 \mathrm{ml} 0.4 \mathrm{M} \mathrm{NH}_{4} \mathrm{Cl} / 200 \mathrm{~g}$ body weight at 12 -hr intervals. Controls (๑) received simultaneously $5 \mathrm{ml} 0.4 \mathrm{M} \mathrm{NaCl} / 200 \mathrm{~g}$ body weight. At $48 \mathrm{hr}$ (zero time, 0700 hr Greenwich Mean Time) all animals were given $10 \mathrm{ml} 0.3 \mathrm{M} \mathrm{NaHCO}$ in $10 \%$ glucose, and were subsequently allowed access to $20 \mathrm{~mm} \mathrm{NaHCO}_{3}$ in $0.18 \% \mathrm{NaCl}$ ad lib. Tissue extractions and assays were performed as described in the Methods section. Results are expressed as the means \pm SEM of four observations in each case.

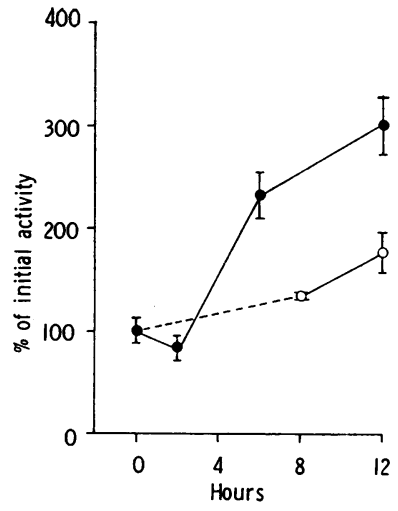

FIGURE 5 Time-course of the changes in rat liver PEPCK after triamcinolone. Rats (approximately $150 \mathrm{~g}$ ) were injected intramuscularly with $2.5 \mathrm{mg} / 100 \mathrm{~g}$ body weight of triamcinolone acetonide (experimentals, $O$ ) or a similar volume of $0.9 \% \mathrm{NaCl}$ (controls, $\bullet$ ) at zero time $(0700 \mathrm{hr}$ ). Tissue extractions and assays were performed as described in the Methods section. Results are expressed as the means \pm SEM of four observations in each case.

PEPCK activity (17) (Fig. 5). The activity in control livers is increased $200 \%$ at $12 \mathrm{hr}(1900 \mathrm{hr}$ GMT $)$. In contrast, triamcinolone, at the high dosage used abolishes this rhythm and activity at $12 \mathrm{hr}$ is only slightly increased over that at zero time. Longer timecourses, not shown, reveal that PEPCK activity under these conditions rises more slowly in the first $24 \mathrm{hr}$

TABLE III

Kinetic Parameters of the Decay of Kidney PEPCK Activity after Triamcinolone and $\mathrm{NH}_{4} \mathrm{Cl}$

\begin{tabular}{|c|c|c|c|c|c|c|}
\hline Experiment & Parameter & $\begin{array}{r}\text { Predi } \\
\text { PEF } \\
\text { (m }\end{array}$ & $\begin{array}{l}\text { d values for } \\
\text { activities } \\
\text { is } \pm \text { SEM) }\end{array}$ & $\begin{array}{l}\text { Rate constant for } \\
\text { PEPCK decay } \\
\left(\mathrm{hr}^{-1} \pm \mathrm{SD}\right)\end{array}$ & $P$ & $(\mathrm{hr} \pm \mathrm{t}$ \\
\hline Decay after triamcinolone & & {$\left[\begin{array}{l}\text { Start } \\
\text { Final }\end{array}\right.$} & $\begin{array}{l}22.1 \pm 1.3 \\
11.6 \pm 0.6\end{array}$ & $0.51 \pm 0.16$ & & $1.37 \pm 0.52$ \\
\hline Decay after $\mathrm{NH}_{4} \mathrm{Cl}$ & & $\begin{array}{l}\text { Start } \\
\text { Final }\end{array}$ & $\begin{array}{r}15.8 \pm 1.3 \\
4.3 \pm 0.8\end{array}$ & $0.21 \pm 0.05$ & & $3.28 \pm 1.01$ \\
\hline Decay after triamcinolone & $\mathrm{mU} / \mathrm{mg}$ soluble protein & $\left\{\begin{array}{l}\text { Start } \\
\text { Final }\end{array}\right.$ & $\begin{array}{l}260 \pm 17 \\
133 \pm 7\end{array}$ & $0.57 \pm 0.23$ & $<0.02$ & $1.21 \pm 0.59$ \\
\hline Decay after $\mathrm{NH}_{4} \mathrm{Cl}$ & & $\begin{array}{l}\text { Start } \\
\text { Final }\end{array}$ & $\begin{array}{r}268 \pm 22 \\
71 \pm 14\end{array}$ & $0.19 \pm 0.05$ & & $3.59 \pm 1.05$ \\
\hline Decay after triamcinolone & $\mathrm{U} / 100 \mathrm{~g}$ body weight & Start & $\begin{array}{l}19.5 \pm 1.4 \\
10.7 \pm 0.7\end{array}$ & $0.41 \pm 0.16$ & $<0.05$ & $1.69 \pm 0.81$ \\
\hline Decay after $\mathrm{NH}_{4} \mathrm{Cl}$ & & $\begin{array}{l}\text { Start } \\
\text { Final }\end{array}$ & $\begin{array}{r}13.1 \pm 1.1 \\
3.5 \pm 0.6\end{array}$ & $0.21 \pm 0.05$ & & $3.32 \pm 0.99$ \\
\hline
\end{tabular}

The derivation of constants is given in the Methods section and is discussed in the text. Predicted values for PEPCK activities are those given in the computer output. 
TABLE IV

Effect of Triamcinolone and Acidosis on the Rates of Synthesis of Kidney PEPCK

\begin{tabular}{lrrcrcr}
\hline \multicolumn{1}{c}{ Inducer } & $\mathrm{t}_{0}$ & $\mathrm{t}_{\mathrm{f}}$ & $\mathrm{P}_{\mathrm{o}}$ & \multicolumn{1}{c}{$\mathrm{P}_{\mathrm{t}}$} & $\mathrm{S}^{\prime}$ & $\mathrm{S}^{\prime} / \mathrm{S}$ \\
\hline \multirow{3}{*}{ Triamcinolone } & $h r$ & $h r$ & $U / \mathrm{s}$ & $U / \mathrm{g}$ & & \\
& 2 & 6 & 2.61 & 5.02 & 2.74 & 1.79 \\
& 6 & 8 & 5.02 & 6.81 & 3.99 & 2.61 \\
$\mathrm{NH}_{4} \mathrm{Cl}$ & 8 & 10 & 6.81 & 9.37 & 5.51 & 3.60 \\
& 10 & 12 & 9.37 & 10.89 & 5.99 & 3.92 \\
& 4 & 8 & 3.82 & 7.21 & 2.05 & 1.06 \\
& 8 & 10 & 7.21 & 8.66 & 2.40 & 1.24 \\
& 10 & 12 & 8.66 & 10.35 & 2.85 & 1.47 \\
\hline
\end{tabular}

The method of calculation was as discussed in the text. $t_{0}$ is the lower time point, $t_{f}$ the higher time point; $P_{0}$ is the enzymic activity at $t_{0}$, and $P_{f}$ is the activity at $t_{f} . S$ is the normal rate of enzyme synthesis (as given in the text) and $\mathrm{S}^{\prime}$ is the "induced" rate of synthesis.

than in the $24-48 \mathrm{hr}$ period. Maximum activity is reached at $48 \mathrm{hr}$.

Derivation of kinetic constants for PEPCK turnover. Computer analysis of the PEPCK activity decay curves (9) after triamcinolone and $\mathrm{NH}_{4} \mathrm{Cl}$ yields the kinetic constants shown in Table III. The first order rate constant, $k^{\prime}$, for the decay after steroid is approximately $0.5 \mathrm{hr}^{-1}$, corresponding to a half-life of only $1.4 \mathrm{hr}$.

The normal rate of synthesis (S) is given by

$$
\mathrm{S}=\mathrm{kP}
$$

where $\mathrm{k}$ is the zero order rate constant for synthesis and $P$ is the steady-state level of enzyme activity. Since triamcinolone-induced enzyme is similar to normal "noninduced" PEPCK on the basis of antibody crossreactivity and molecular weight studies $(1,18)$, it is reasonable to assume that $\mathrm{k}^{\prime}$ equals $\mathrm{k}$. By substitution of the value for the normal noninduced $\mathrm{PE}$ PCK activity $(3.0 \mathrm{U} / \mathrm{g})$ in equation 2 , the normal rate of synthesis is found to be $1.53 \mathrm{U} / \mathrm{hr}$. In the experiment involving measurement of the decay of PEPCK activity after $\mathrm{NH}_{4} \mathrm{Cl}$, the normal noninduced level of PEPCK activity was $3.8 \mathrm{U} / \mathrm{g}$ kidney. Using the value of $\mathrm{k}$ already determined, the normal rate of synthesis in this case was $1.94 \mathrm{U} / \mathrm{hr}$.

The new rates of synthesis after induction with both steroid and $\mathrm{NH}_{4} \mathrm{Cl}$ were calculated as suggested by Haining (19), using equation 3 ,

$$
S^{\prime}=\frac{k^{\prime}\left(P_{0} e^{-k^{\prime} t}-P_{f}\right)}{e^{-k^{\prime} t}-1}
$$

where $S^{\prime}$ is the new rate of enzyme synthesis, $P_{0}$ is the value for enzyme activity at the lower time point chosen, $P_{\boldsymbol{x}}$ is the value for enzyme activity at the higher time point chosen, $t$ is the time interval separating $P_{0}$ and $P_{s}$, and $k^{\prime}$ is the rate constant for degradation as determined. The results of these calculations are given in Table IV. Triamcinolone induces an increase in the rate of PEPCK synthesis which is nonlinear; this resembles the situation observed with other enzyme activities in rat liver (19). The new rate of synthesis approaches a value of approximately 4 times the normal rate at $12 \mathrm{hr}$. With $\mathrm{NH}_{4} \mathrm{Cl}$ induction, however, the "induced" rate of synthesis is only slightly greater than the normal rate, indicating that $\mathrm{NH}_{4} \mathrm{Cl}$ has a minimal effect on de novo PEPCK synthesis rates, and must therefore exert most of its "inductive" effect on other processes including enzyme degradation.

\section{DISCUSSION}

Some previous reports have suggested that the activities of liver gluconeogenic enzymes are increased in a concerted manner in adrenalectomized animals treated with triamcinolone $(20.21)$. This phenomenon has been attributed to the direct stimulation of a "functional genome" by the inducer. In normal animals. in contrast, the response of these same enzymes is more complex. Of the liver enzymes, PEPCK activity alone is sensitive towards induction by triamcinolone. while in the kidney both glucose-6-phosphatase and PEPCK are responsive. The differences between liver and kidney glucose-6-phosphatases may possibly be attributed to the properties of two distinct protein entities controlled by separate genes. Liver and kidney PEPCK. on the other hand, are immunologically indistinguishable (1), and presumably represent the activity of a single protein species. Despite this, the time-courses of PEPCK induction by triamcinolone in the two tissues are clearly different (see Figs. 1 and 5). In view of these findings, it is apparent that the processes of induction in vivo may be considerably more complex than would be expected from a simple, single, action of the hormone upon either transcription or translation.

The rates of degradation of enzyme protein are preferably determined from labeling and immunoprecipitation data (22), although recent caveats have been made $(23,24)$ regarding this approach. In the absence of sufficient specific antisera, however, calculations based on detailed measurements of activity alone may serve as a useful first approximation. The apparent half-life of kidney PEPCK after single triamcinolone injections is $1.4 \mathrm{hr}$. It may be objected that this figure represents merely the decline in enzyme activity parallel with and related to the decline in the tissue steroid content. Florini, Peets, and Buyske (15), however, have shown that the half-life of triamcinolone in rat blood is 52 min, and that a very small percentage only is retained 
in the kidney after $24 \mathrm{hr}$. Nevertheless, in view of the initial pharmacological dosage given to each animal, this residual steroid may be sufficient to explain the observation that PEPCK activity decays only to a point significantly above the control value. The figure of $1.4 \mathrm{hr}$ should thus more properly be considered a mean maximal value for the half-life of kidney PEPCK. This value is much shorter than the $9-16 \mathrm{hr}$ reported by Reshef, Ballard, and Hanson, (25) for the apparent half-life of the immunologically similar adipose tissue PEPCK (18), but is in the range reported for several enzymes of regulatory significance in rat liver (26-28).

The half-life of PEPCK after acidosis is considerably longer $(3.4 \mathrm{hr})$. Since acidosis may be terminated rapidly with $\mathrm{NaHCO}_{3}$, it is concluded that the observed rate of decay of PEPCK activity truly reflects the turnover of active enzyme and is not limited by the rate of removal of the "inducer."

It is apparent that the two processes whereby kidney PEPCK total activity is increased are clearly distinguished kinetically. The increased rate of synthesis of PEPCK with triamcinolone, together with the known sensitivity of this process to actinomycin $D(1,2)$ and ethionine (2) indicate that steroid effects are most likely mediated through de novo production of enzyme protein. In acidosis, however, changes in the rate of "synthesis" appear to be small in comparison with changes in the rate of degradation. The insensitivity of PEPCK "induction" in acidosis to RNA synthesis inhibitors $(1,2)$ indicates that de novo synthesis is not obligatory for increased ability. Since the "induced" PEPCK activity exhibits a similar antibody titer to that of normal PEPCK, the presence of an inactive precursor molecule must be considered (1). Inhibition of the rates of protein degradation alone is insufficient to explain an increase in immunotitrable enzyme activity; it is simultaneously required that synthetic activity is maintained. If de novo synthesis is ruled out, the present results are consistent with the postulate of an inactive polypeptide precursor. Under these circumstances the premises upon which equation 1 are based are no longer valid, and the rate of change of enzyme activity is dependent on the concentration of precursor molecules ( $\mathrm{E}^{*}$ ) (equation 4),

$$
\frac{d E}{d t}=k_{1} E^{*}-k^{\prime} E
$$

where $k_{1}$ is the first order rate constant for the activation reaction. (Equation 4 is, of course, further modified if the activation process involves either association or dissociation of precursor subunits.) If $\mathrm{E}^{*}$ is relatively large in comparison with $\mathrm{E}$, as suggested by the insensitivity of the process to actinomycin $\mathrm{D}$ for a period of as long as $48 \mathrm{hr}$, then equation 4 may be treated in a manner similar to equation 1 and the values obtained experimentally for $\mathrm{k}^{\prime}$ may be taken to approximate those of the true decay rate constant.

The pathways by which PEPCK activity decays in alkalosis are not distinguished in the present study. At least three possibilities present themselves, viz., (a) conversion to "normal" PEPCK (1), (b) proteolysis by a pathway distinct from that of the "normal" enzyme, and (c) reconversion into the inactive species. Further kinetic analysis must therefore await the characterization of the enzymic species involved, together with an understanding of their interconversion.

\section{ACKNOWLEDGMENTS}

We thank Dr. P. J. England for his help with the computation of results and Professor P. J. Randle for his interest and encouragement. The cost of these investigations was defrayed by grants from the British Diabetic Association, the Medical Research Council, and the British Insulin Manufacturers to Professor Randle and by a grant from Imperial Chemical Industries Ltd., to Dr. Longshaw.

\section{REFERENCES}

1. Longshaw, I. D., and C. I. Pogson. 1972. The effect of steroids and ammonium chloride acidosis on phosphoenolpyruvate carboxykinase in rat kidney cortex. I. Differentiation of the inductive processes and characterization of enzyme activities. J. Clin. Invest. 51: 2277.

2. Flores, H., and G. A. O. Alleyne. 1971. Phosphoenolpyruvate carboxykinase of kidney. Subcellular distribution and response to acid-base changes. Biochem. J. 123 : 35.

3. Alleyne, G. A. O., and G. H. Scullard. 1969. Renal metabolic response to acid base changes. I. Enzymatic control of ammoniagenesis in the rat. J. Clin. Invest. 48: 364 .

4. Bruce, H. M., and A. S. Parkes. 1949. Feeding and breeding of laboratory animals. IX. A complete cubed diet for mice and rats. J. Hyg. 47: 202.

5. Nordlie, R. C., and W. J. Arion. 1966. Glucose 6-phosphatase. Methods Enzymol. 9: 619.

6. Huggett, A. St. G., and D. A. Nixon. 1957. Enzymatic determination of blood glucose. Biochem. J. 66: 12P

7. Underwood, A. H., and E. A. Newsholme. 1965. Some properties of fructose 1,6-diphosphatase of rat liver and their relation to the control of gluconeogenesis. Biochem. J. $95: 767$.

8. Layne, E. 1957. Spectrophotometric and turbidimetric methods for measuring proteins. Methods Enzymol. 3: 447.

9. Haining, J. L. 1971. On the kinetics of liver enzyme regression following induction. Arch. Biochem. Biophys. 144: 204.

10. Freedland, R. A., and A. E. Harper. 1957. Metabolic adaptations in higher animals. I. Dietary effects on liver glucose-6-phosphatase. J. Biol. Chem. 228: 743.

11. Foster, D. O., H. A. Lardy, P. D. Ray, and J. B. Johnston. 1967. Alteration of rat liver phosphoenolpyruvate carboxykinase activity by L-tryptophan in vivo and metals in vitro. Biochemistry. 6: 2120.

12. Lardy, H. A., D. O. Foster, J. W. Young, E. Shrago, and P. D. Ray. 1966. Hormonal control of enzymes 
participating in gluconeogenesis and lipogenesis. J. Cell. Comp. Physiol. 66 (Suppl. 1) : 39.

13. Wicks, W. D. 1971. Differential effects, of glucocorticoids and adenosine $3^{\prime} 5^{\prime}$-monophosphate on hepatic enzyme synthesis. J. Biol. Chem. 246: 217.

14. Freedland, R. A., E. H. Avery, and A. R. Taylor. 1968. Effect of thyroid hormones on metabolism. II. The effect of adrenalectomy or hypophysectomy on responses of rat liver enzyme activity to L-thyroxine injection. Can. J. Biochem. 46: 141.

15. Florini, J. R., E. A. Peets, and D. A. Buyske. 1961. Plasma half-life, tissue distribution, and excretion of triamcinolone $-{ }^{3} \mathrm{H}$. J. Pharmacol. Exp. Ther. 131: 287.

16. Alleyne, G. A. O. 1970. Renal metabolic response to acid-base changes. II. Early effects of metabolic acidosis on renal metabolism in the rat. J. Clin. Invest. 49: 943.

17. Phillips, L. J., and L. J. Berry. 1970. Circadian rhythm of mouse liver phosphoenolpyruvate carboxykinase. Am. J. Physiol. 218: 1440.

18. Ballard, F. J., and R. W. Hanson. 1969. Purification of phosphoenolpyruvate carboxykinase from the cytosol fraction of rat liver and the immunochemical demonstration of differences between this enzyme and the mitochondrial phosphoenolpyruvate carboxykinase. J. Biol. Chem. 244: 5625 .

19. Haining, J. L. 1970. Kinetics of induction of rat liver enzymes by glucocorticoids. Mol. Pharmacol. 6: 444.

20. Ashmore, J., and G. Weber. 1968. Hormonal control of carbohydrate metabolism in liver. In Carbohydrate Metabolism and its Disorders. F. Dickens, P. J.
Randle, and W. J. Whelan, editors. Academic Press Inc., New York. 1: 335.

21. Weber, G., R. L. Singhal, N. B. Stamm, and S. K. Srivastava. 1965. Hormonal induction and suppression of liver enzyme biosynthesis. Fed. Proc. 24: 745.

22. Gelehrter, T. D. 1971. Regulatory mechanisms of enzyme synthesis: enzyme induction. In Enzyme Synthesis and Degradation in Mammalian Systems. M. Rechcigl, Jr., editor. Karger, Basel. 165.

23. Poole, B. 1971. The kinetics of disappearance of labelled leucine from the free leucine pool of rat liver and its effect on the apparent turnover of catalase and other hepatic proteins. J. Biol. Chem. 246: 6587.

24. Klevecz, R. 1971. Rapid protein catabolism in mammalian cells is obscured by reutilisation of aminoacids. Biochem. Biophys. Res. Commun. 43: 76.

25. Reshef, L., F. J. Ballard, and R. W. Hanson. 1969. The role of the adrenals in the regulation of phosphoenolpyruvate carboxykinase of rat adipose tissue. $J$. Biol. Chem. 244 : 5577.

26. Marver, H. S., A. Collins, D. P. Tschudy, and $M$. Rechcigl, Jr. 1966. $\delta$-aminolevulinic acid synthetase. II. Induction in rat liver. J. Biol. Chem. 241: 4323.

27. Kenney, F. T. 1967. Turnover of rat liver tyrosine transaminase: stabilisation after inhibition of protein synthesis. Science (Wash., D. C.). 156: 525.

28. Schimke, R. T., E. W. Sweeney, and C. M. Berlin. 1965. The roles of synthesis and degradation in the control of rat liver tryptophan pyrolase. J. Biol. Chem. $240: 322$. 